\title{
Discursul judiciar utilizat de aparatul inchizitorial ${ }^{1}$
}

\author{
Judicial Discourse Used by the Inquisition
}

\begin{abstract}
Mihai Floroaia $^{2}$
Rezumat: Sursele de cercetare privind discursurile judiciare sunt constituite din colecțiile de legi și decrete, bulele papale, canoanele bisericești, actele conciliilor, analele monastice, istoriile comunităților locale și abațiilor, procesele-verbale ale proceselor desfășurate, sentințele proceselor inchizitoriale, biografiile episcopilor, papilor, diverse panegirice etc. Acestora li se adaugă diverse coduri de procedură penală sau manuale pentru uzul inchizitorilor, ghiduri după care erau recunoscute persoanele care practicau vrăjitoria, legislația care se aplica în cazul condamnării ereticilor și a persoanelor care propovăduiau alte învățături decât cea predicată de Biserica Apuseană. Toate acestea oferă numeroase detalii despre modul în care erau organizate și se desfășurau procesele inchizitoriale.
\end{abstract}

Cuvinte cheie: discurs, inchiziție, juridic, proces, surse

\begin{abstract}
Among the sources of research on the judicial discourse one may find collections of laws and decrees, papal bulls, church canons, council acts, monastic annals, histories of local communities and abbeys, minutes of trials, sentences of inquisitions, biographies of bishops and popes, various eulogies and so on. To these are added various codes of criminal procedure or manuals for the use of inquisitors, guides according to which were recognized persons who practiced witchcraft, the legislation applicable to convicting heretics and persons who taught other teachings than those preached by the Western Church. All these sources provide many details on the way in which inquisitorial processes were organized and conducted.
\end{abstract}

Keywords: discourse, inquisition, legal, trial, sources

Privind întreaga perioadă în care a activat Inchiziția sub diverse forme/etape (Inchiziția romană, Inchiziția medievală, Inchiziția pontificală, Inchiziția monahală, Inchiziția spaniolă etc.), din anul 1183 (când a fost înființată de Conciliul de la Verona în vederea pedepsirii ereticilor, respectiv anul înființării oficiale, 1231) și până la abolirea ei pe 15 iulie 1834, legislația utilizată a înregistrat permanente modificări de la o regiune la alta, de la un interval de timp la altul. Începând cu secolul al XIV-lea, instituția bisericii și-a organizat o bază juridică foarte solidă cu instanțe în fiecare localitate. Din aceste tribunale făceau parte și persoane cu

1 Prezentul studiu este extras din conținutul lucrării Inchiziția între mit și realitate, Editura Presa Universitară Clujeană, Cluj-Napoca, 2016.

2 Profesor doctor, Colegiul Tehnologic „Spiru Haret”, Piatra-Neamț, mihaifloroaia@gmail.com. 
pregătire juridică, ceea ce oferea o garanție în plus în fața cetățenilor. În asemenea context, cadrul juridic al epocii (legislația civilă urbană și legislația bisericească) a contribuit la apariția a ceea ce s-a numit ulterior inquisitio heretice pravitatis.

Ca surse de cercetare privind discursurile judiciare avem colecțiile de legi și decrete, bulele papale, canoanele bisericești, actele conciliilor, analele monastice, istoriile comunităților locale și abațiilor, procesele-verbale ale proceselor desfășurate, sentințele proceselor inchizitoriale, biografiile episcopilor, papilor, diverse panegirice etc. Acestora li se adaugă diverse coduri de procedură penală sau manuale pentru uzul inchizitorilor, ghiduri după care erau recunoscute persoanele care practicau vrăjitoria, legislația care se aplica în cazul condamnării ereticilor și a persoanelor care propovăduiau alte învățături decât cea predicată de Biserica Apuseană. Toate acestea oferă numeroase detalii despre modul în care erau organizate și se desfășurau procesele inchizitoriale.

Etapele unui proces desfășurat de Inchiziție, și anume vizita inchizitorului, predica și timpul de grație, ancheta cu denunțarea suspecților, interogatoriul acuzaților, citarea și audierea martorilor, intervenția avocatului, constrângerea, pronunțarea sentinței, executarea pedepsei etc., ne oferă informații consistente privind modul în care era organizat întregul proces judiciar.

Sursele la care nu am avut acces direct le-am citat după cercetătorii care au analizat problematica lor, însă le-am verificat comparativ din diferite lucrări și studii, pentru a obține o imagine obiectivă. Colecțiile de legi, bule papale și scrisori ale Vaticanului, alături de diverse normative, constituie sursele de bază pentru a analiza rolul pe care l-au avut tribunalele inchizitoriale în perioada analizată.

Chiar dacă, imediat după momentul înființării Inchiziției, aceasta nu avea o procedură riguroasă, ancheta era realizată de către personalul bisericesc (în special preoți), având concursul auxiliarilor specializați. Episcopul și arhiepiscopul fiecărei dioceze, personal sau reprezentat de un diacon (ori de altă persoană „onestă și capabilă”), vizitau parohiile unde era semnalată prezența ereticilor o dată sau de două ori pe an. Episcopul sau reprezentantul său obliga prin jurământ trei sau mai multe persoane să depună mărturie și să denunțe toate ereziile și comportamentele suspecte. „Episcopul sau arhidiaconul său, sau alte persoane corecte și cinstite să inspecteze o dată sau de două ori pe an parohia în care s-a zvonit că locuiesc eretici."3 Cei care refuzau să depună jurământ erau consideraţi eretici.

Până spre finalul secolului al XII-lea, episcopii urmăreau în diocezele lor orice problemă de credință și luau măsurile necesare pentru evitarea răspândirii ereziilor. Bula Ad abolendam din 4 noiembrie 1184, care permitea urmărirea sistematică a ereticilor, lăsa totul la latitudinea episcopilor. ${ }^{4}$ Dacă, în ansamblu, după

3 Decretum Gratiani, Causa XXIV, Întrebarea III, canon 26-31, Edition E. Friedberg, Leipzig, 1879, apud H. Maisonneuve, Études sur les origines de l'inquisition (Col. L'Église et l'état au Moyen Âge, VII), deuxième édition revue et augmentée, Librairie philosophique J. Vrin, Paris, 1960, p. 152.

4 E. Friedberg, Corpus Iuris Canonici. Pars 2. Decretalium Collectiones, Leipzig, B. Tauchnitz, 1881, réimp. Clark, New Jersey, The Lawbook Exchange, 2000, 780 - 782; MANSI, t. XXII, col. 492. 
Conciliul Lateran IV (1215) nu s-au produs modificări majore privind modul de funcționare a Inchiziției, mai multe concilii locale, spre exemplu cel din anul 1227 de la Narbonne ${ }^{5}$ și cel de la Toulouse din 1229, subliniau rolul episcopilor în combaterea ereziilor, oferindu-le acestora dreptul de practică. Conciliul din Toulouse menționa și pedepsele ce vor fi administrate în funcție de greșelile săvârșite, stabilind că pedeapsa cu închisoarea putea fi considerată o cale de penitență. ${ }^{6}$

În anul 1231, papa Grigore al IX-lea hotăra că judecarea infracțiunilor de erezie este în exclusivitate de competența instanțelor ecleziastice, autoritățile laice având doar misiunea de a aplica pedepsele. ${ }^{7}$ În 1233, același papă a încredințat călugărilor dominicani misiunea de inchizitori. ${ }^{8}$ In anul 1246 papa Inocențiu al IV-lea dă aceeași misiune și călugărilor franciscani. ${ }^{9}$ Astfel, procedura era stabilită de bulele papale sau de un ansamblu de texte redactate de conciliile provinciale. Cel mai vechi text este scris între anii 1244 și 1254 de 4 dominicani: Guillaume Raymond, ${ }^{10}$ Pierre Durand, Bernard de Caux ${ }^{11}$ și Jean de Saint-Pierre ${ }^{12}$, care activaseră în Languedoc. ${ }^{13}$

În decursul timpului au apărut mai multe coduri de procedură pentru inchizitori și persoanele din aparatul inchizitorial. Aceste coduri, împreună cu procedura inchizitorială și cu retorica inchizitorilor, ne oferă elemente importante privind discursul judiciar al acestui aparat. Voi prezenta, succint, câteva dintre codurile (codex-urile) reprezentative pentru tema abordată. ${ }^{14}$

MANSI, t. XXIII, col. 19-26.

MANSI, t. XXIII, col. 194-205.

7 L. Auvray, Les Registres de Grégoire IX, recueil des bulles de ce pape d'après les manuscrits originaux du Vatican, tome premier, Librairie des Écoles françaises d'Athènes et de Rome, Paris, 1896, n 535, 539, 540, 541, col. 348-354.

8 Ms. 609, fol. 58v, Biblioteca Municipală din Toulouse. Cf. J. Feuchter, Pierre Sellan (12341242), un vieillard expérimenté, în L. Albaret, Les Inquisiteurs. Portraits de défenseurs de la foi en Languedoc (XIII ${ }^{e}-X I V^{e}$ siècles), Éditions Privat, Toulouse, 2001, p. 45.

$9 \quad$ Primul inchizitor franciscan a fost Étienne de Saint-Thibéry (1235 - 1242). Prin bula dată de papa Inocențiu al IV-lea la 13 ianuarie 1246, li se acorda franciscanilor misiunea de a urmări ereticii. Cf. P. Fredericq, Corpus Documentorum Inquisitionis haereticae pravitatis Neerlandicae, tome I, $\mathrm{n}^{\circ} 12$ și Th. de Cauzons, Histoire de l'Inquisition en France, t. I, Librairie Bloud \& Cie, Paris, 1909, p. 453, $\mathrm{n}^{\mathrm{o}} 1$.

10 *** Des hommes et des inquisiteurs, în L. Albaret, Les Inquisiteurs. Portraits de défenseurs de la foi en Languedoc (XIII - XIVe siècles), Éditions Privat, Toulouse, 2001, p. 166.

11 Une figure d'inquisiteur : Bernard de Caux, în Le Credo, la Morale et l'Inquisition, Cahiers de Fanjeaux, 6, Éditions Privat, Toulouse, 1971, pp. 253-272.

$12{ }^{* * *}$ Des hommes et des inquisiteurs, în L. Albaret, Les Inquisiteurs. Portraits de défenseurs de la foi en Languedoc (XIII - XIVe siècles), Éditions Privat, Toulouse, 2001, p. 166.

13 A. Reltgen-Tallon, L'image de l'Inquisition et des dominicains au Moyen Âge, în L. Albaret, Les Inquisiteurs. Portraits de défenseurs de la foi en Languedoc (XIII ${ }^{e}-X^{2} V^{e}$ siècles), Éditions Privat, Toulouse, 2001, pp. 153-159.

14 Vezi M. Floroaia, Inchiziția între mit și realitate, Editura Presa Universitară Clujeană, Cluj-Napoca, 2016, pp. 108-122. 
Grațian (1090-1155), prin Decretele (Decretale) $)^{15}$ sale, a pus problema reprimării ereziilor printr-o manieră completă care făcea să fie descoperiți ereticii. Au constituit un cod de procedură din care se vor inspira mai târziu inchizitorii. De exemplu, întrebarea 23 conține 166 de canoane și se referă la situații concrete: „Dacă unui anume episcop îi cade turma în erezie, el este obligat să pună credincioșii din zonă la post și rugăciune. Papa dispune puterii civile să ancheteze situația..." ${ }^{16} \mathrm{Ni}$ se oferă exemple de întrebări la care trebuiau să răspundă persoanele suspecte de erezie: E păcat să faci război? Poate fi războiul drept? Este bine să fie confiscate bunurile ereticilor și bisericile lor? etc. La toate aceste întrebări sunt oferite și posibilele răspunsuri.

Întrebarea a XXIV-a: „Un oarecare episcop decăzut în erezie a fost privat de drepturile sacramentale (de a oficia slujbele). După moartea sa a fost acuzat de erezie și condamnat împreună cu familia sa și partizanii săi. Apar trei întrebări posibile: Un eretic poate fi privat de funcție (slujbă) și să fie supus cenzurii? Poate fi el excomunicat după moarte? Pentru păcatele sale, poate fi excomunicată toată familia lui?' Chestiunea a XXIV-a cuprinde 24 de canoane. ${ }^{17}$

La statornicia principiilor și regulilor de funcționare, a scopurilor urmărite și a mijloacelor au contribuit și enciclicele, legislația laică, însă cele mai importante au fost "manualele inchizitorilor" ${ }^{18}$ Acestea ocupă un loc privilegiat printre instrumentele de studiere a Inchiziției. Din cauza dificultăților întâmpinate de inchizitori, cei care aveau o pregătire teoretică și experiență practică au elaborat adevărate ghiduri pentru instruirea personalului tribunalelor Inchiziției, ca de exemplu:

Decretales, o colecție de texte de maximă utilizare întocmită de Raymond de Pennafort în anul 1230 la ordinul papei Grigorie al IX-lea. ${ }^{19}$ Cuprinde detalii despre statutul și mandatul inchizitorilor, ${ }^{20}$ descrie pe iudei și sarazini,${ }^{21}$ oferă amănunte despre eretici ${ }^{22}$, schismatici ${ }^{23}$ și apostați ${ }^{24}$, etc., precum și măsurile ce trebuie luate împotriva tuturor acestora. Cel mai vechi manual cunoscut al Sfântului Oficiu

15 Decretele juristului Grațian au apărut în anul 1140. Vezi A. Winroth, The Making of Gratian's Decretum, University Press, Cambridge, 2000.

16 Monumenta Germaniae Historica. Legum, II: Capitularia Regum Francorum: I, p. 407.

17 Apud H. Maisonneuve, op. cit., p. 67.

18 Acestea cuprindeau legi referitoare la pedepsirea ereticilor și normative pentru personalul care făcea parte din tribunalele inchizitoriale.

19 Vezi Gregorius IX, Pont. Max., Decretales, cum glossa, Lyons, Johannes Siber, aproximativ 1485 și Decretals of Pope Gregory IX in E. L. Richter, E. Friedberg (ed.), Corpus Iuris Canonici, Pars Secunda: Decretalium Collectiones, Leipzig, 1881; Regesta..., $\mathrm{n}^{\mathrm{o}} 1463$.

$20{ }^{* * *}$ Decretales D. Gregorii Papae IX (Suae integritati una cun glossis. Restituae ad exemplar Romanum), Venetiis, MDCV, De Electione, etc. Lib. I, Tit. VI, cap. XXVI, pp. 107-108.

21 Idem, Decretalium Gregorii, Lib. V, Tit. VI, De Iudaeis et Sarracenis, pp. 1162-1182.

22 Idem, Lib. V, Tit. VII De hereticis, pp. 1182-1184.

23 Idem, Lib. V, Titulus VIII De schismaticis, cap. I și II, pp. 1184-1185.

24 Idem, Lib. V, Tit. IX De apostatis et reinterantibus baptisma, pp. 1185-1188. 
datează din anul 1244, având denumirea de Ordo processus Narbonensis ${ }^{25}$. Alcătuit într-un mod sumar, cuprindea procedura și pedepsele inchizitoriale. Procedura era următoarea: citarea generală, timpul de grație, interogatoriul în 14 puncte și formulele de condamnare. ${ }^{26}$ Acest ghid reprezintă sinteza misiunii inchizitoriale a dominicanilor Guillaume Raymond și Pierre Durant. Începe cu o scrisoare din 21 octombrie 1244 a provincialului Ponce de Lesppare din Provence, trimisă celor doi inchizitori, prin care solicita aprobarea pentru urmărirea ereticilor din Narbonne și din diocezele Albi, Rodez, Mende și Puy. Conținutul ne prezintă patru aspecte ale proceselor: modul în care ereticii sunt judecați de brațul secular, condamnarea la închisoare a ereticilor, pedepsele de penitență și exhumarea și arderea cadavrelor persoanelor decedate în erezie. În primele două situații se menționează clar că membrii tribunalului și juriștii, fără inchizitor, vor decide la cererea consiliului. În cazul ultimelor două cazuri, inchizitorii nu erau secondați de episcopi sau reprezentanţi ai Bisericii, nici de oamenii legii. ${ }^{27}$ Tratatul se încheie cu trei declarații (mărturisiri): prima face referire la prezentarea sentinței în prezența clerului și poporului, a doua se referă la spiritul dreptății care îi ghidează pe inchizitori, fiind reprodusă prima parte a canonului 23 de la Conciliul Narbonne din anul 1243: „Amintim și impunem condamnările și penitențele după ce au fost convocați clerul și poporul, conform obiceiului și la momentul potrivit. Nu am procedat la condamnarea nimănui fără probe clare și concludente sau fără mărturisirea proprie și nu procedăm în continuare, să dea Dumnezeu. Și toate condamnările și penitențele mai deosebite pe care le-am făcut și le facem, le prezentăm nu numai în mare, dar chiar în amănunt consiliului prelaților." ${ }^{28}$ A treia mărturisire se referă la confiscarea bunurilor ereticilor predați brațului secular.

De Inquisitione haereticorum, atribuit inchizitorului franciscan David d'Augsbourg (1256-1271), descrie semnele după care pot fi recunoscuți ereticii, obiceiurile lor și mai ales vicleniile acestora. Cercetarea ereticilor are la bază experiența autorului în calitate de tânăr inchizitor. ${ }^{29}$ De modo procedendi contra haereticos $^{30}$, apărut între anii 1278-1298, este practic o compilație: o parte din actele Conciliului de la Tarragona (definițiile diverselor categorii de eretici) și Ordo processus Narbonensis, totalizând 21 de formule.

25 A fost descoperit de dominicanul P. François Balme în Biblioteca Universității din Madrid, înregistrat sub cota 53 și publicat de M. Ad. Tardif în Nouvelle Revue historique de droit français et étranger, Paris, 1883, pp. 670-678. Cf. E. Vacandard, L'Inquisition. Étude historique et critique sur le pouvoir coercitif de l'Église, Paris, 1912, Appendices, p. 313.

26 E. Vacandard, op. cit., Appendice A, pp. 313-321.

27 H. Maisonneuve, op. cit., p. 331.

28 Can. 23 Sinodul Narbonne. Cf. Hefele-Leclercq, Histoire des Conciles d'après les documents originaux, tome V, deuxième partie, livre XXXVI, chapitre III, Paris, 1913, p. 1632.

29 E. Martene, U. Durand, Thesaurus novus anecdotorum, t. IV-V, Paris, 1717, col. 1778-1794, apud H. Maisonneuve, op. cit., p. 332, nota 172.

30 A. Dondaine, Le Manuel de l'Inquisiteur, în Archivum fratrum praedicatorum, vol. XVII, Roma, 1947, pp. 108-111. 
Practica officii Inquisitionis haereticae pravitatis (Practica anchetării depravării eretice), întocmit în anul $1324^{31}$ de Bernard Gui, inchizitor de Toulouse (1307$1324)^{32}$, este un tratat folosit de inchizitori, fiindu-le facilitată descoperirea ereziei în Toulouse, Carcasses, Alpi, provincia ecleziastică Narbonne, adică diocezele Narbonne, Agde, Béziers, Carcassonne, Aleth, Elne, Lodève, Maguelonne etc. și diocezele vecine. Documentul a fost publicat pentru prima dată la Paris în anul 1886. ${ }^{33}$ Lucrarea este împărțită în cinci părți. Prima conține 38 de formule privind citarea și prinderea ereticilor precum și înfățișarea tuturor persoanelor într-un proces al inchiziției. În a doua parte sunt 56 acte de grațiere sau comutare a greșelilor făcute în cursul sau în afara predicilor generale pronunțate de inchizitori. A treia parte are 46 de formule pentru sentințe date cu ocazia acelor predici. Primele trei părți au avut drept surse actele notarilor inchiziției episcopale și sentințele Inchiziției din Toulouse publicate de Philippi Limborch. ${ }^{34}$ Toate acestea au fost fie redate integral, fie modificate pentru a omite numele celor interesaţi, datele și locurile, având un caracter impersonal. Bernard Gui a extras informații despre cele trei trepte ierarhice admise de valdenzi (episcop, preot, diacon) dintr-un registru al inchiziției din Pamiers, mai exact din mărturisirile unui diacon al sectei, pe nume Raymond de la Côte Saint-André, în $1320 .{ }^{35}$ Partea a patra constă într-o „scurtă şi utilă instrucțiune” cu privire la puterile inchizitorilor, excelența, importanța, fundamentele lor. ${ }^{36}$ Acest mic tratat are ca model scrierile scolastice și juridice ale vremii, fiind alcătuit din fragmente și extrase din edictele imperiale, consultații juridice, constituțiile apostolice ce sunt trecute sau nu în Quorumdam (Corpus juris canonici) promulgat la 7 octombrie 1317 de papa Ioan al XXII-lea. Capitolele cu privire la evrei și la magicieni/vrăjitori se regăsesc într-un manuscris al Inchiziției franceze din secolul al XIII-lea, aflat astăzi la Biblioteca Mazarine din Paris. ${ }^{37}$

A cincea parte reprezintă opera de artă a lui Bernard Gui, intitulată „Metodă, artă și procedee folosite pentru căutarea și interogarea ereticilor, credincioșilor și a complicilor lor." Aici sunt redate doctrinele și riturile la cathari ${ }^{38}$, valdenzi ${ }^{39}$,

31 B. Gui, Manuel de l'inquisiteur, (Col. Les classiques de l'histoire de France au Moyen Âge), editat și tradus de G. Mollat, Paris, 1926-1927, pp. XI-XV.

32 A. Dubreil-Arcin, Bernard Gui, un inquisiteur méthodique, în L. Albaret, Les Inquisiteurs. Portraits de défenseurs de la foi en Languedoc (XIII ${ }^{e}-$ XIVe siècles), Éditions Privat, Toulouse, 2001, pp. 112-113.

33 Practica Inquisitionis heretice pravitatis, auctore B. Guidonis O.F.P., publié pour la première fois par C. Douais, Paris, 1886. Cf. Introduction, din B. Gui, Manuel de l'inquisiteur..., tome Irer, Paris, 1964, p. V.

$34 \mathrm{Ph}$. a Limborch, Historia Inquisitionis cui subjungitur Liber sententiarum inquisitionis Tholosanae (ab anno CIJCCCVII ad annum CI CCCXXIII), Amstelodami, apud H. Wetstenium, CIכI כ CXCII (1692).

35 B. Gui, Manuel de l'inquisiteur ..., tome II, Paris, 1964, pp. 148-152.

36 Ibidem, Apendice II. Acta diversa ad Officium Inquisitoris pertinentia, pp. 123-153.

37 Manuscrisul nr. 2015, fol. 116r, datat din anul 1180, care conține un extract din opera lui Étienne de Bourbon. Cf. B. Gui, Manuel de l'inquisiteur, ..., vol. I, pp. 34-35.

38 B. Gui, Manuel de l'inquisiteur..., vol. I, pp. 10-22.

39 Ibidem, pp. 34-58. 
pseudo-apostoli ${ }^{40}$, precum și modul în care trebuie să decurgă interogatoriile acestor eretici. ${ }^{41}$ Sunt și câteva pagini consacrate iudeilor convertiți care se reîntorc la iudaism, vrăjitorilor, invocatorilor demonilor, ghicitorilor, precum și câteva exemple de practici ale acestora. Această parte a lucrării nu este originală ${ }^{42}$ deoarece sunt întâlnite asemănări cu tratatul din 1250 al inchizitorului italian Rainier Sacchoni, intitulat Summa de Catharis et Leonistis (capitolul consacrat inchiziției catharilor din Toulouse, interogatoriile suferite de „perfectul” Pierre Autier). ${ }^{43}$ Capitolul consacrat valdenzilor depinde de mici tratate, din care patru sunt principale: De septem donis Spiritus Sancti al lui Étienne de Bourbon (secolul al XIII-lea), Disputatio inter catholicum et paterinum hereticum (secolul al XIII-lea), consultația episcopului din Tarragona (1242), De inquisitione hereticorum al lui David d'Augsbourg (1256-1271). Gui cunoștea lucrarea De septem donis Spiritus Sancti, compusă de fratele predicator Étienne de Bourbon între anii 1250 și 1261, din care citează adesea. Étienne a studiat la Universitatea din Paris și a trăit la mănăstirea din Lyon din 1223, de unde a cules informații despre originea valdenzilor de la concetățenii lui Petru Valdus și de la un benedictin al catedralei, Étienne d'Anse, care a lucrat la traducerea în limba populară a Bibliei și a maximelor scrise de Părinții Bisericii. El a vorbit în predicile sale despre valdenzii din dioceza Valence în 1235, apoi a făcut cunoștință cu ei când a fost numit inchizitor. ${ }^{44}$ Gui la copiat reproducând anumite date imprecise, cu unele greșeli. Dar el nu a avut niciun merit pentru că numele lui Augustin, Ambrozie, Ieronim și Grigore figurau şi în tratatul inchizitorului Moneta (1240), intitulat Adversus Catharos et valdenses. ${ }^{45}$ O altă sursă este aceea a unui autor anonim, a cărui operă a fost publicată de Martene în Disputatio inter catholicum et paterinum hereticum ${ }^{46}$, în care este descris ritualul euharistiei la valdenzi. Bernard Gui l-a copiat, adăugând că săvârșitorul nu avea rangul de preot consacrat în mod legal de către un episcop catolic. Gui a introdus și un capitol din consultația episcopului din Tarragona, Pierre d'Albalat. Printre alte izvoare documentare consultate de autor menționăm: un manual francez compus în 1280, imprimat de Martene și Durand, conținând Doctrina de modo procedendi contra hereticos, care relatează procedura utilizată de inchizitori în Carcasses și Toulouse ${ }^{47}$; De inquisitione hereticorum a lui David d'Augsbourg, din care Bernard Gui a copiat, modificând uneori textul; tratatul autorului anonim italian scris pe 1 mai $1316^{48}$, unde Gui a modificat conținutul și a inserat unele

$40 \quad$ Ibidem, pp. 384-394.

41 Ibidem, pp. 26-32, 76-82 și 98-104.

42 Ibidem, pp. XVI-XXV.

43 E. Martene, U. Durand, Thesaurus..., t. V, col. 1775-1800, apud B. Gui, op. cit., tome Ir, Introduction, p. XXI.

44 B. Gui a cunoscut opera dominicanului É. de Bourbon, De septem donis Spiritus Sancti (scrisă între anii 1250 și 1261), din care citează adesea. Cf. B. Gui, op. cit., vol. I, Introduction, pp. XIX-XX.

45 Ibidem, p. XXI și pp. 34-36.

$46 \quad$ Ibidem, p. 42.

47 Ibidem, p. XXI.

48 B. Gui, op. cit., vol. I, p. XXIII. 
informații de la Pierre de Lugo ${ }^{49}$; o altă sursă cu privire la ceremonii, ritualuri de reîntoarcere la iudaism, precum și la doctrinele iudaice pentru tribunalul său, etc.

Anchetele trebuiau să se desfășoare în cel mai strict secret. Acuzatul era arestat de la început pe baza unei simple bănuieli. Astfel, inculpatul era socotit vinovat înainte de a fi cercetat: „... față de anumiți eretici inchizitorul nu trebuie să fie blând, ci procedând cu discernământ să dejoace în așa fel șiretlicurile ereticilor, incât, cu ajutorul Domnului, să smulgă din rădăcini, ca o moașă îndemânatică, șarpele unduitor din cloaca și hăul păcatelor." ${ }^{\circ}$

„Practica anchetării depravării eretice” ne oferă numeroase amănunte asupra unor aspecte ale derulării anchetelor în zonele unde activau tribunalele prezidate de el. Dacă unele bănuieli, rumoarea publicului, denunțurile sau acuzațiile atrăgeau atenția lui Bernard Gui, acesta îl cita pe cel în cauză pentru a apărea în fața lui, la Toulouse, în sediul Inchiziției, aproape de castelul Narbonnais, unde se afla mănăstirea Fraților Predicatori. ${ }^{51}$ Preotul, căruia i se încredința citația, se ducea la domiciliul enoriașului său și o citea în prezența unor martori demni. Duminica următoare, în timpul slujbei, el o recitea în fața clerului și a credincioșilor. Se citea în trei duminici, ea fiind numită „fără replică - irevocabilă”. Ordinul inchizitorului era autentificat de pecetea preotului și de actul notarial. Cel care nu apărea sau nu era reprezentat de un procuror era „judecat în lipsă” și excomunicat provizoriu. După un an de la citarea inculpatului, judecătorul pronunța o sentință de excomunicare definitivă, interzicându-i-se orice schimb cu vecinii săi, și amenințându-i pe aceștia că, dacă nu vor dezvălui locul unde se ascundea, cădeau sub pedeapsă canonică. Dar uneori treceau ani până când inchizitorul ajungea la asemenea acte extreme.

Citația era folosită numai în cazul celor preveniți care puteau fi eliberați provizoriu. În caz contrar, Bernard Gui, care se mândrea cu autoritatea papei și a regelui Franței, cerea puterii civile să-i aresteze și să-i dea pe mâna temnicerului Inchiziției din Toulouse. Suspecții suportau toate cheltuielile, de exemplu pentru mâncarea și întreținerea prizonierilor. Este posibil ca regele Franței să le fi ordonat oficialilor săi (conți, baroni, judecători etc.) să-i ajute pe inchizitori în exercițiul funcțiunii și să se supună ordinelor acestora.

Interogatoriul se făcea de către inchizitor în prezența a doi credincioși cu discernământ, iar notarul redacta procesul verbal al mărturiilor. Fiind un exponent al justiției, inchizitorul urma regulile acesteia, bucurându-se de „privilegii speciale”, care-l autorizau să procedeze simplu și direct, fără artificii avocățești sau prezentări introductive. El apela la aplicarea canonului 37 de la cel de-al patrulea Conciliu Lateran $(1215)^{52}$, care interzicea citarea unui martor ce stătea la mai mult de două zile depărtare de domiciliul acuzatului. Dacă un „prevenit” invoca

49 Ibidem.

50 D. Cosma, Socrate, Bruno, Galilei în fața justiției, Editura Sport-Turism, București, 1982, p. 105.

51 Practica Inguisitionis heretice pravitatis, éd. Douais, Paris, 1886, p. 3, 4, 6, 8, 9, 10, 12, 15 , 22, 25, apud ediția din 1964, vol. I, pp. XLV-XLVI.

$52{ }^{* * *}$ Corpus juris canonici, Decretales Gregorii IX, lib. I, tit. III, cap. XXVIII. 
tribunalul inchizitorial și cel episcopal în același timp, Bernard Gui amintea regula veche care prevedea acționarea în libertate a oricărei persoane cu privire la alegerea judecătorului. Dacă un eretic fugea de acuzații, inchizitorul îl reclama ca fiind în custodia lui, astfel luându-i dreptul judecătorului care putea să-l pună în libertate. Vina era astfel stabilită: mărturisirea celui acuzat sau prin alți martori (probe); se admiteau și mărturisirile „infame” ale criminalilor sau excomunicaților. În cazul în care mărturiile nu coincideau, judecătorul constata dacă erau în concordanță cu „substanța faptei.” Numele martorilor erau ținute secrete de teama represaliilor. ${ }^{53}$ Urmează celelalte etape ale procesului precum: constrângerea, sentința, pedeapsa, inchisoarea, semnele infamiei, pelerinajele, pedepsele pecuniare, confiscarea bunurilor, distrugerea caselor ereticilor, incapacitățile etc.

Bernard Gui prezintă și formula tip a primei penitențe: „T, Tinând cont de faptul că ești cetățean citat ca suspect, acuzat, denunțat ca adept al beghinilor ${ }^{54}$ (Frații săraci ai celui de-al treilea ordin al Sfântului Francisc) care acționează împotriva Bisericii sfinte și universale și a puterii apostolice, ai făcut demersul unei judecăți în fața noastră. N., inchizitor, te-am somat să mărturisești (tu și complicii tăi) cu privire la erezie, la greșeli și credințe greșite față de Biserică, papă, prelați. Tu ai refuzat, așa că eu, inchizitorul N., te condamn de trei ori să fii excomunicat, să juri pe Sfânta Evanghelie, fără nicio condiție sau rezervă, să spui tot adevărul despre tine și complicii tăi vii sau morți, să declari tot ce știi sau ai văzut, ce crezi despre erezie (despre greșelile lor), despre beghini și inclusiv tot ce ține de această problemă. Prin bunăvoințăa iți dau un răgaz până la ora 6, al doilea răgaz de la 6 la 9 și al treilea de la 9 până la ziua judecății. Dacă nu ai jurat până când expiră răgazul, cu virtutea apostolică cu care am fost învestit și în exercițiul funcției inchizitoriale, te excomunic și dau o sentință de excomunicare (vei avea o copie a acestei decizii)." 55

Ghidul oferă unele instrucțiuni cu privire la viclenia celor care nu răspund cu claritate sau răspund vag și echivoc: „Sunt beghini care sunt vicleni și se ascund sau disimulează și, de teamă să nu fie prinși, răspund vag și ambiguu în termeni generali și confuzi, de exemplu: „eu cred ce crede Biserica lui Dumnezeu; credința mea e aceeași ca a ei" și se abțin de la alte detalii." "Interogatoriul trebuie astfel făcut cu perspicacitate și discernământ: „Ce înțelegi prin Biserica lui Dumnezeu? Ce este?’57 Inchizitorul trebuia să aibă abilitatea de a-i constrânge pe acești indivizi și de a-i determina să răspundă clar, discernând sensul răspunsurilor vagi și confuze.

Tot în partea a V-a a manualului sunt prezentate unele „blasfemii intolerabile” ale iudeilor împotriva lui Hristos și a religiei creștine: „Fii binecuvântat Dumnezeule, regele etern care nu m-ai făcut nici creștin, nici bun. Să nu ai milă pentru cei pierduți (convertiți la religia lui Hristos) la fel pentru eretici sau atei; să fie

53 Practica..., éd. Douais, pp. 189-191.

54 R. Manselli, Spirituels et béguins du Midi, trad. Jean Duvernoy, Bibliothèque Historique Privat, Paris, 1989.

55 B. Gui, op. cit., vol. I, pp. 182-186.

56 Ibidem, p. 176.

57 Ibidem, pp. 154-156 și 188-190. 
exterminați toți dușmanii tăi. Fie ca regatul nedreptății să fie distrus în bucăți." 58 Termenii „eretici” și „regat” se referă la creștini. Evreii reclamă un regat atotputernic care va distruge regatul ereticilor, adică al creștinilor. Acest Dumnezeu al lor va fi adorat de toți, iar toate regiunile se vor închina lui și-i vor jura credință. Toți vor deveni robi pe vecie și acest Dumnezeu va domni veșnic. Toate acestea sunt blasfemii contra creștinilor; aceste injurii sunt redate într-o lucrare a iudeilor francezi, „Maazor” ${ }^{59}$, într-o culegere de rugăciuni, „Typhilloth”. Ei se roagă la Dumnezeu de trei ori pe zi să-i distrugă pe creștini, considerându-i eretici. O altă operă este Glosă pe textul legii ${ }^{60}$, unde se regăsesc pasaje, cuvinte, idei eronate din Talmud împotriva lui Hristos, pe care evreii nu-L consideră Dumnezeu și om, cu atât mai puțin Mesia. Ei consideră eretici/infideli pe cei care urmează calea lui Hristos. O altă operă, Explicarea și reinstituirea Legii (Glosa lui Moise în Egipt) ${ }^{61}$ conține vicleșuguri și falsuri din Talmud împotriva credinței creștine (împotriva ereticilor numiți „minim” în ebraică). Se spune că Hristos a acționat împotriva lui Dumnezeu și a legii Sale greșind mai mult decât Mahomed, atrăgând lumea să adore un alt Dumnezeu decât pe Cel Unic. De asemenea, Glosa lui David spaniolul ${ }^{62}$ reprezintă o explicație a Cărții Psalmilor și conține atacuri împotriva lui Hristos, a credincioșilor și adepților creștinismului.

Dacă, după anchetă și mărturisire sub jurământ, o persoană vrea să se pocăiască sincer, trebuie ca înainte de a fi absolvită de excomunicare să renege orice erezie. Formula de renegare, și anume „Eu, N., în prezența inchizitorului și a Sfinților Evangheliști, reneg orice erezie condamnată de Biserică (în special cea a sectelor), renunț la sectă și la riturile și partizanii acesteia, promit să-i dezvălui și săi aduc pe eretici în fața Inchiziției, promit să practic și să apăr credința catolică, să respect regulile Bisericii și ale inchizitorilor, să apar în fața lor oricând voi fi chemat, să accept penitența dată..." ${ }^{3}$, era consemnată de notar sub forma unei declarații scrise. Aceasta avea următorul conținut: „Numitul N. a renegat orice erezie practicată de eretici și de orice sectă condamnată de Biserica romană; el a promis să urmeze regulile Bisericii”, etc. ${ }^{64}$ La sfârșitul procesului se concluziona: „Sus-numitul N. a fost absolvit de excomunicare cu condiția ca întoarcerea la unitatea ecleziastică să fie făcută din toată inima și doar dacă a îndeplinit toate prescripțiile impuse și a confesat tot adevărul despre erezie. A făcut mărturisirile sub jurământ și s-a angajat să respecte promisiunile; doi oameni religioși pot nota toate acestea; notarul va citi în limba vulgară tot ce a scris: mărturisirea, prezența martorilor, promisiunile inculpatului de a se lăsa de erezie." ${ }^{65}$ Cei din secta valdenzilor aveau o formulă specială de renegare: „Eu, N., reneg orice erezie împotriva Domnului nostru Iisus Hristos și a Sfintei Biserici,

58 Ibidem, vol. II, pp. 12-19.

59 The Jewish Encyclopedia, t. VIII, New York, 1903, pp. 262-264.

60 B. Gui, op. cit., vol. II, p. 18.

61 Ibidem.

62 Ibidem.

63 Ibidem, p. 26.

64 Ibidem, p. 28.

65 Ibidem, pp. 30-32. 
erezie comisă de secta valdenzilor sau de Săracii din Lyon cu care am avut relații, leam îmbrățișat greșelile și în care am crezut. Reneg orice doctrină; nu mai vreau să mă număr printre eretici. Promit să-i denunț pe ceilalți, în special pe ereticii valdenzi...."66 Dacă inculpatul mărturisea totul, renega erezia și se căia sincer, i se dădea un titlu de fidelitate și i se acorda o penitență. Inculpatul citat și acuzat de erezie care refuza să mărturisească era arestat. Putea fi eliberat pe cauțiune (în funcție de statutul social) când nu erau dovezi clare sau acuzația nu era directă, ci doar bazată pe unele suspiciuni. Cei eliberați pe cauțiune stăteau în fiecare zi la ușa inchizitorului. Dar acest lucru nu a fost benefic întotdeauna pentru că acuzații se grupau și se sfătuiau. Un suspect arestat mai mulți ani mărturisea în cele din urmă toate greșelile posibile din cauza presiunii psihice. În enumerarea ereziilor, după Bernard Gui, vrăjitoria ocupă ultimul loc. ${ }^{67}$ Inspirat din lunga experiență a autorului, fără îndoială, manualul este celebru, fiind utilizat de inchizitori în diverse conjuncturi ale secolelor XIV-XV.

Directorium inquisitorum ${ }^{68}$ este scris la Avignon, în anul $1376^{69}$ de Nicolau Eymerich ${ }^{70}$, inchizitor general în Catalonia și Aragon. ${ }^{71}$ Tratatul reprezintă primul manual tipărit de acest fel. A fost tipărit în anul 1503 și reeditat în perioada 15781607 de cinci ori (de trei ori la Roma în anii 1578, 1585, 1587 și de două ori la Veneția în anii 1595 și 1607). ${ }^{72}$ Plasează vrăjitoria la finalul caracterizărilor principalelor erezii. Fenomenul magic apare divizat în două capitole: primul dedicat clarvăzătorilor și ghicitorilor, iar al doilea invocatorilor diavolului. Este dezvoltat cultul diavolului, indicându-se diverse forme de practicare și distingându-se mai

66 Ibidem, pp. 34-36.

67 Ibidem, pp. 20-24 și 134-136.

68 Îndrumătorul sau Manualul Inchizitorilor. Am utilizat ediția Albin Michel, Paris, 2001 (N. Eymerich, Le manuel des inquisiteurs avec les commentaires de Francisco Peña, introducere, traducere și note de L. Sala-Molins, Éd. Albin Michel, Paris, 2001).

69 G. Foucoi, Consultationes ad inquisitores haereticae pravitatis, citat de L. Sala-Molins în N. Eymerich, op. cit., Introducere, pp. 14-15.

70 S-a născut în anul 1320 la Gérone (regatul Catalonia - Aragon). În 1334 (la 14 ani) intră în ordinul dominicanilor, la Mănăstirea Sfântul Dominic, în orașul natal. În 1357 devine inchizitor general de Catalonia, Aragon, Valencia și Mallorca, urmându-l în funcție pe dominicanul Nicolau Rossell, ajuns cardinal în 1356. Și-a exersat funcția între 1357 și 1392, cu două mari întreruperi: 1360-1365 și 1375-1387. În două reprize (între 1377 și 1378 și între 1393 și 1397) a fost exilat din teritoriile aflate sub coroana Catalonia și Aragon. În anul 1362 devine vicar general al ordinului dominican; în 1397 revine la mănăstirea Sfântul Dominic din Gérone, unde va sta până în 1399. Cf. N. Eymerich, op. cit., Introducere, p. 14 nota 1 și pp. 14-15.

71 Eymerich a scris numeroase lucrări ca: Tratat de logică, Tratat împotriva celor ce invocă demonii, Despre jurisdicția inchizitorilor contra necredincioșilor care acționează împotriva sfintei noastre credințe catolice, Tratat despre autoritatea papală, Tratat împotriva alchimiștilor etc. Cf. ${ }^{* * *}$ Scriptores Ordinis Praedicatorum recensiti, notisque historicis et criticis, vol. I, apud J. B. Christophorum Ballard et N. Simart, Lutetiae Parisiorum, MDCCXIX, pp. $709-713$.

72 N. Eymerich, op. cit., p. 19. 
multe tipuri de invocaţii: sacrilegiile, rugăciunile, jurămintele, promisiunea de slujire. Lucrarea cuprinde trei părți: despre credința catolică și despre înrădăcinarea sa, despre răutatea eretică care acționează împotriva credinței catolice și, ceea ce este esențial, practica oficiului. ${ }^{73}$

Manualul îi prevenea pe inchizitori să nu primească denunțuri contra ereticilor cu ocazia spovedaniei. Eymerich spunea că fiecare inchizitor trebuie să aibă un caiețel în care să-și noteze numele tuturor denunțătorilor, pentru ca la nevoie să fie folosite ca martori. Îi avertizează pe inchizitori să nu considere „erezie” ceea ce s-a spus în glumă. Erau date sfaturi anchetatorilor cu privire la interogarea învinuiților: „Este bine ca în timpul interogatoriului acuzatul să stea pe un scaun mai scund, mai umil decât jilțul inchizitorului. Interogatoriul trebuie condus în așa fel încât să se evite a i se sugera acuzatului ce anume se vrea de la el... să se meargă de la general la particular și de la special la singular..."74

Inchizitorul e îndemnat să fie abil, iscusit, prefăcut, viclean, pregătit oricând să întindă curse ereticilor. Pentru acele persoane care evită sub diverse forme recunoașterea învinuirilor aduse, autorul enumeră „10 vicleșuguri ale inchizitorului pentru a le contracara pe cele ale ereticilor": inchizitorul să spună că va pleca curând într-o călătorie departe și dacă acuzatul nu răspunde cât mai repede întrebărilor puse, va aștepta mult timp în închisoare întoarcerea anchetatorului și va fi torturat. ${ }^{75}$ Acestea sunt prezentate simetric față de „10 vicleșuguri ale ereticilor pentru a răspunde fără a mărturisi”: răspunsul în doi peri, răspunsul anihilat de o condiție, răspunsul printr-o altă întrebare, simularea surprizei, răspunsul la o întrebare nepusă, divagația, autojustificarea, simularea leșinului, etc. ${ }^{76}$ Referitor la tortură, Eymerich spunea că: „este neîndoielnic vrednic de laudă să se aplice tortura, dar eu dezaprob cu tărie pe acei judecători sângeroși care, pentru nu știu ce glorie, se dedau la schingiuiri rafinate și atât de crude încât învinuiții mor sub tortură sau își pierd unele mădulare." 77 In concluzie, opera lui Eymerich reprezintă mai mult decât un manual, este un "directuar" pentru inchizitori. ${ }^{78}$

Compilación de las instrucciones del Oficio de la Sancta Inquisición... ${ }^{79}$ a fost întocmit de faimosul inchizitor Thomas de Torquemada. Prima ediție a apărut în 1484, apoi s-au reeditat alte trei ediții în anii 1485, 1488 și 1498. Este numit și „codul terorii". A avut drept model Directorium inquisitorum al lui N. Eymerich. Autorul a eliminat ceea ce ținea exclusiv de Roma și a avut ca referință tribunalul inchiziției spaniole. Lucrarea a fost alcătuită într-un moment delicat atât pentru coroana

Ibidem, p. 18 și pp. 73-298.

Ibidem, p. 161.

Ibidem, pp. 169-173.

Ibidem, pp. 165-169.

Ibidem, p. 263.

78 A. Dondaine, Le manuel de l'inquisiteur, în Archivum Fratrum Praedicatorum, 17, 1947, pp. 85-194.

79 Compilație a instrucțiunilor Oficiului Sfintei Inchiziții...Cf. Paginii de titlu a primei ediții tipărite în anul 1576, păstrată în Biblioteca British Museum, reprodusă de R. Sabatini, op. cit., p. 127. 
Spaniei, cât și pentru reorganizarea instituției inchizitoriale. Torquemada a beneficiat și de contribuțiile altor inchizitori: Deza, Cisneros, Maurique și Valdés. ${ }^{80}$ Instrucțiunile cuprindeau organizarea și procedura inchizitorială care erau deja stabilite prin legislația conciliară, decretele papilor și diverse manuale. Articolul 15 face referire la acuzații care se vor autodenunța: „cei ce se vor învinui pe ei înșiși iș̦i vor prezenta mărturisirea în scris inchizitorilor și notarilor lor, cu doi sau trei martori, care vor fi slujbași ai inchiziției sau alte persoane integre." ${ }^{81}$ Putem concluziona că Inchiziția spaniolă nu are aspecte originale în contextul epocii privind legislația, mai ales că în anul 1503 s-a editat, la Barcelona, manualul lui Eymerich.

Dacă primele „instrucțiuni” date de Torquemada în anul 1484 cuprindeau 28 de articole având ca punct de plecare manualele lui Bernard Gui și Nicolas Eymerich, timp de aproximativ zece ani, în intervalul octombrie 1488-mai 1498, Torquemada a adăugat unele aspecte suplimentare privind modul de organizare și funcționare a tribunalelor. ${ }^{82}$ Spre exemplu, în cadrul „noilor” instrucțiuni, în primele trei articole face precizări privind remunerarea personalului tribunalelor. ${ }^{83}$

Primele trei articole relatau modul în care inchizitorii se prezintă în localitățile unde își vor exercita mandatul, însoțiți de preoți, stareți și guvernatorii locali, constituirea tribunalului, predica și timpul de grație. ${ }^{84}$

Articolul XXV prevedea excomunicarea tuturor persoanelor care primeau atribuții în cadrul tribunalelor inchizitoriale (notari, avocați, fiscali, etc.) și refuzau aceste demnități. ${ }^{85}$

Normele de procedură acordau și o oarecare larghețe inchizitorului. De exemplu, articolul XXVIII prevedea ca, în cazul unei situații neprevăzute de prezentul cod inchizitorial, inchizitorii vor proceda în conformitate cu legislația în vigoare, după libera conștiință, fiind conștienți de faptul că sunt în serviciul Domnului și al regalității. ${ }^{86}$ Instrucțiunile lui Torquemada au fost reeditate și în secolul al XVII-lea, respectiv în anul 1667, la Madrid.

Sacro Arsenale ${ }^{87}$ al inchizitorului Eliseo Marsini a fost editat în anul 1631, după care a fost reeditat de șase ori, tratatul fiind utilizat foarte des de către Inchiziția romană. Manualul ne pune în gardă împotriva iluziilor diabolice provocate în cadrul diverselor exorcisme. Vrăjitoria este limitată la actele ce implică pactul cu diavolul, apostazia credinței și eficacitatea acțiunilor malefice. Recomandă prudență în desfãșurarea anchetelor și în ceea ce privește acceptarea

80 Articolul Inquisición, în Diccionario de la Historia Eclesiástica de España, Madrid, 1972, p. 1195, col. B.

81 Cf. R. Sabatini, op. cit., pp. 137-139 și p. 209; D. Cosma, op. cit., p. 101.

82 R. Sabatini, op. cit., p. 149 și 204-210.

83 Ibidem, p. 205-206.

84 Ibidem, pp. 128-129.

85 Ibidem, p. 148.

86 Ibidem, p. 149.

87 E. Masini, Sacro Arsenale, overo Prattica dell'Officio della Santa Inquisizione, Et in questa secunda impressione corretta..., Roma, 1705. Cf. A. Agnoletto, Sacro arsenale de Bologna 1665, Milano, 1990. 
mărturiilor. În ediția Bologna, 1665, apărută sub titlul Sacro Arsenale, overo Practica dell Officio della Santa Inquisizione, se menționează că tortura trebuie aplicată doar în cazul în care inchizitorul e de părere că acuzatul este complet vinovat. Noțiunea de corp delict apare foarte strict delimitată, fapt ce demonstrează evoluția culturii juridice a inchizitorilor.

În anul 1246, Conciliul de la Béziers ${ }^{88}$ stabilea regulile de drept substanțial și procesual cărora trebuiau să li se supună inchizitorii în activitatea lor, iar bula $A d$ extirpanda ${ }^{89}$ din 15 mai 1252 emisă de papa Inocențiu al IV-lea proclama lupta de exterminare a ereticilor drept o îndatorire fundamentală a statelor creștine. Aceasta obliga pe toți creștinii, indiferent de statutul lor social, să denunțe orice erezie. În intervalul 1254-1264, sub papii Alexandru al IV-lea și Urban al IV-lea, Inchiziția dobândește toate atribuțiile. ${ }^{90}$

Misiunea inchizitorilor în scrisorile de împuternicire se definea astfel: „Noi, $N$., prin grația divină (...) Inchizitor general, cu încredere în scrisorile de recomandare și în dreapta voastră conștiință, N., prin autoritatea apostolică, vă creăm și vă instituim inchizitor apostolic împotriva depravării eretice și apostaziei în tribunalul Inchiziției din N., în districtul și jurisdicția lui. Și vă învestim cu puterea și facultatea (...) de a ancheta toate persoanele, oricare ar fi ele, bărbat sau femeie, în viață sau decedate, absente sau prezente, de orice stare, condiție, prerogative sau demnitate, absolvite sau nu, rezidente sau cu domiciliul temporar, care au locuit permanent sau temporar în orașele, târgurile și satele din districtul respectiv, care s-au făcut vinovate, suspecte sau dezonorate prin delicte și crime de erezie și apostazie și pe toți incitatorii, apărătorii și tăinuitorii lor. Și pentru ca să porniți împotriva lor și a fiecăruia dintre ei procese potrivit legii și Sfintelor Canoane...." 91 Timp de aproximativ patru secole, din anul 1480 până în 1820, formula nu s-a modificat, scopul rămânând același: anchetarea, prevenirea și combaterea ereziilor.

Din cele prezentate reiese faptul că ghidurile sau manualele pe care le utilizau inchizitorii aveau o anumită structură și o tipologie a întrebărilor ce erau adresate suspecților/persoanelor anchetate de tribunalele inchizitoriale.

Inchiziția a îndeplinit și rolul de poliție politică, asigurând controlul străinilor care străbăteau un anumit stat, deoarece aceștia erau primii suspectați de erezie.

Eliminând miturile, exagerările, fabulațiile, etc. create în jurul Inchiziției și analizând cu obiectivitate documentele păstrate putem afirma că, în realitate, acest

$88^{* * *}$ Sacrorum Conciliorum nova et amplissima collectio, tomus vigesimus tertius, Mansi (Ioannes Dominicus Mansi, archiepiscopus Lucensis evulgavit), Veneția, MDCCLXXIX, ed. Leipzig, 1903, col. 715-718.

89 Magnum Bullarium Romanum. Bullarum privilegiorum ac diplomatum Romanorum Pontificum amplissima collectio, tomus tertius, pars prima, Innocentius Quartus, XXVII, Romae, MDCCXL, reimp. Graz, 1964, pp. 324-327.

90 A se vedea privilegiile acordate membrilor tribunalelor prin bulele papale. Magnum Bullarium Romanum. Bullarum privilegiorum ac diplomatum Romanorum Pontificum amplissima collectio, tomus tertius, pars prima, Alexander Quartus, XLVI - LIV, pp. 389394 și Urbanus Quartus, IV, pp. 404-406, Romae, MDCCXL, reimp. Graz, 1964.

91 N. Eymerich, op. cit., pp. 138-139; B. Bennassar, Inchiziția spaniolă secolele XV-XIX, trad. de Carmela Roman, Editura Politică, București 1983, p. 11. 
Judicial Discourse Used by the Inquisition

aparat coercitiv a acționat printr-o diversitate de mijloace și metode mult mai dur decât ne putem imagina.

\section{Referințe}

Albaret L., Les Inquisiteurs. Portraits de défenseurs de la foi en Languedoc (XIII - XIVe siècles), Éditions Privat, Toulouse, 2001

Auvray L., Les Registres de Grégoire IX, recueil des bulles de ce pape d'après les manuscrits originaux du Vatican, vol. I, Librairie des Écoles françaises d'Athènes et de Rome, Paris, 1896

Bennassar B., Inchiziția spaniolă, trad. Carmela Roman, Editura Politică, București, 1983

Cauzons Th. de, Histoire de l'Inquisition en France, vol. I, Librairie Bloud \& Cie, Paris, 1909

Cosma D., Socrate, Bruno, Galilei în fața justiției, Editura Sport-Turism, București, 1982

*** Corpus juris canonici, Decretales Gregorii IX, lib. I, tit. III, cap. XXVIII

${ }^{* * *}$ Decretales D. Gregorii Papae IX (Suae integritati una cun glossis. Restituae ad exemplar Romanum), Venetiis, MDCV

Diccionario de la Historia Eclesiástica de España, Madrid, 1972

Dondaine A., Le Manuel de l'Inquisiteur, în Archivum fratrum praedicatorum, vol. XVII, Roma, 1947

Douais M. (évêque de Beauvais), L'Inquisition. Ses origines. Sa procédure, Paris, Librairie Plon, 1906

Dumea E., Teme de istorie a Bisericii, Editura Sapientia, Iași, 2002

*** Encyclopédie Théologique, Dictionnaire de droit et de jurisprudence en matière civile ecclésiastique, Migne, t. 37, 1849

Eymerich N., Le manuel des inquisiteurs avec les commentaires de Francisco Peña, introducere, traducere și note de L. Sala-Molins, Ed. Albin Michel, Paris, 2001

Floroaia M., Inchiziția între mit și realitate, Editura Presa Universitară Clujeană, ClujNapoca, 2016

Fredericq P., Corpus Documentorum Inquisitionis haereticae pravitatis Neerlandicae, vol. I, f.a.

Friedberg E., Corpus Iuris Canonici. Pars 2. Decretalium Collectiones, Leipzig, B. Tauchnitz, 1881, réimp. Clark, New Jersey, The Lawbook Exchange, 2000

Gui B., Manuel de l'inquisiteur, (Col. Les classiques de l'histoire de France au Moyen Âge), editare și traducere de G. Mollat, Paris, 1926-1927

Gui B., Practica Inquisitionis heretice pravitatis, publicată pentru prima dată de C. Douais, Paris, 1886

Héfelé Ch.-J., Histoire des conciles d'après les documents originaux, trad. fr. corr. et augm. par dom H. Leclercq, Letouzey \& Ané, Paris, 1913-1938

Hiatt-Verill A., Inchiziția, trad. rom. de Gh. Dinu, Editura Casa Școalelor, Craiova, 1939

Horia V., Dicționarul Papilor, trad. de A. Vădeanu, Editura Saeculum I.O., București, 1999

Jaffé Ph., Loewenfeld S., Regesta pontificum Romanorum, vol. II, Lipsiae, 1888

*** Le Credo, la Morale et l'Inquisition, Cahiers de Fanjeaux, 6, Éditions Privat, Toulouse, 1971

*** Le livre des sentences de l'inquisiteur Bernard Gui 1308-1323 (sources d'histoire médiévale - 30), vol. I-II, editat, tradus și note de A. Pales - Gobilliard, CNRS Éditions, Paris, 2002

Lea H. Ch., Histoire de l'Inquisition au Moyen Âge, trad. Salomon Reinach, vol. I. Origines et procédure de l'Inquisition, Société Nouvelle de Librairie et d'Édition, Paris, 1903

Lea H. Ch., tome II. L'Inquisition dans les divers pays de la chrétienté, Société Nouvelle de Librairie et d'Édition, Paris, 1901

Lea H. Ch., tome III. Domaines particuliers de l'activité inquisitoriale, Société Nouvelle de Librairie et d'Édition, Paris, 1902 
Llorca P., Bernardino S. J., (ed.), Bulario Pontificio de la Inquisición Española en su período constitucional (1478-1525), según los fondos del Archivo Histórico Nacional de Madrid, Pontificia Università Gregoriana, Roma, 1949

Limborch P., Historia Inquisitionis cui subjungitur Liber sententiarum inquisitionis Tholosanae (ab anno CIכCCCVII ad annum CI CCCXXIII), Amstelodami, apud Henricum Wetstenium, CIכI כ CXCII (1692)

*** Magnum Bullarium Romanum. Bullarum privilegiorum ac diplomatum Romanorum Pontificum amplissima collectio, tomus tertius (a Lucio III ad Clementem IV), Romae, MDCCXL, reimprimat la Akademische Druck - U. Verlagsanstalt, Graz, 1964

Mansi, J. D., Sacrorum Conciliorum nova et amplissima Collectio, édition J.B. Martin et L. Petit, Paris, de la 1901, t. XXII

Maisonneuve H., Études sur les origines de l'inquisition (Col. L'Église et l'état au Moyen Âge, VII), deuxième édition revue et augmentée, Librairie philosophique J. Vrin, Paris, 1960

Manselli R., Spirituels et béguins du Midi, trad. Jean Duvernoy, Bibliothèque Historique Privat, Paris, 1989

Masini E., Sacro Arsenale, overo Prattica dell'Officio della Santa Inquisizione, Et in questa secunda impressione corretta..., Roma, 1705

*** Monumenta Germaniae Historica. Legum, II: Capitularia Regum Francorum: I

Rămureanu I., Istoria Bisericească Universală, vol. II, Editura Institutului Biblic și de Misiune Ortodoxă al Bisericii Ortodoxe Române, București, 1993

*** Sacrorum Conciliorum nova et amplissima collectio, tomus vigesimus tertius, Mansi (Ioannes Dominicus Mansi, archiepiscopus Lucensis evulgavit), Veneția, MDCCLXXIX, ed. Leipzig, 1903

Tanon L., Histoire des tribunaux de l'inquisition en France, Bibliothèque de l'École des chartes, 1894

Testas G. și Testas J., Inchiziția, traducere de I. Cosgarea, Editura de Vest, Timișoara, 1993

*** The Jewish Encyclopedia, t. VIII, New York, 1903

Vacandard E., Inquisition, în Dictionnaire de Théologie Catholique, tome septième, deuxième partie, Paris, 1923

Vacandard E., L'Inquisition. Étude historique et critique sur le pouvoir coercitif de l'Église, Paris, 1912

Winroth A., The Making of Gratian’s Decretum, University Press, Cambridge, 2000 
TRANSLATION PRACTICES 
